\title{
MOVEMENT OF THE WARD HUNT ICE SHELF, ELLESMERE ISLAND, N.W.T., CANADA
}

\author{
By E. DORrer \\ (Department of Surveying Engineering, University of New Brunswick, Fredericton, New \\ Brunswick, Canada)
}

\begin{abstract}
The movement at a marginal location on the Ward Hunt Ice Shelf, northern Ellesmere Island, was determined by repeated survey measurements with theodolite and geodimeter. The purpose and duration of the field work, and reduction of the observational data are described, and the resulting mean ice velocity of $0.53 \mathrm{~m}$ year $^{-1}$ is discussed. Strain-rates of a $\mathrm{I} \mathrm{km}$ by $\mathrm{I} \mathrm{km}$ deformation figure are determined. The parameters $n$ and $B$ of Glen's power flow law are determined by using the equations given by Nye and Weertman. The results are compared with experimental data. Computed ice stresses show that the "ridge-and-trough" structure on the ice shelf surface is not originated by internal ice forces. The elevations of all survey markers have been determined from vertical-angle measurements, and the peculiarities of atmospheric refraction in near-surface layers are discussed.
\end{abstract}

RÉsumÉ. Mouvement de la Ward Hunt Ice Shelf, Ellesmere Island, N.W.T., Canada. Le mouvement sur le bord de la Ward Hunt Ice Shelf au nord de Ellesmere Island, a été déterminé par des mesures répétées au théodolite et au géodimètre. On décrit le but et la durée du travail sur le terrain et la mise en forme des données d'observation, on discute la vitesse moyenne qui en résulte de o,53 $\mathrm{m}$ par an. On détermine la répartition des tensions grâce à un polygone de déformation de $\mathrm{I} \mathrm{km}$ sur $1 \mathrm{~km}$. Les paramètres $n$ et $B$ de la loi puissance de Glen pour l'écoulement sont déterminés en usant les équations données par Nye et Weertman. Les résultats sont comparés aux données de l'expérience. Le calcul des efforts dans la glace montre que la structure en creux et rides de la surface de la calotte glaciaire n'a pas pour origine des forces internes dans la glace. L'altitude de toutes les balises a été déterminée à partir de mesures d'angles verticaux, et les particularités de la réfraction atmosphérique dans les niveaux voisins de la surface sont discutées.

Zusammenfassung. Die Bewegung des Ward Hunt Ice Shelf, Ellesmere Island, N.W.T., Kanada. Die Bewegung eines randnahen Gebietes auf dem Ward Hunt Ice Shelf, nördliche Ellesmere Island, Kanada, wurde durch wiederholte Vermessungen mit Theodolit und Geodimeter bestimmt. Der Zweck und die Dauer der Feldarbeiten, sowie die Reduktion der Beobachtungsdaten werden beschrieben, die resultierende mittlere Eisgeschwindigkeit von $0,53 \mathrm{~m}$ pro Jahr wird diskutiert. Die jährlichen Deformationen eines $I \mathrm{~km} \times I \mathrm{~km}$ grossen Vierecks werden bestimmt. Die Parameter $n$ und $B$ für Glens Fliessgesetz werden durch Anwendung der Gleichungen von Nye und Weertman ermittelt. Die Ergebnisse werden mit experimentell bestimmten Werten verglichen. Die berechneten Eisspannungen zeigen, dass die Wellenstruktur an der Schelfeisoberfläche nicht von inneren Eiskräften hervorgerufen wird. Die Höhen aller Vermessungspunkte wurden aus Vertikalwinkelmessungen bestimmt. Die Eigentümlichkeiten der atmosphärischen Refraktion in oberflächennahen Luftschichten werden diskutiert.

\section{INTRODUCTION}

Between August 196r and April I962 an extensive break-up of the Ward Hunt Ice Shelf, northern Ellesmere Island (lat. $83.2^{\circ} \mathrm{N}$., long. $74^{\circ} \mathrm{W}$.), occurred. A total area of almost $600 \mathrm{~km}^{2}$ calved from the ice shelf to form several large ice islands (Hattersley-Smith, I963). One of these ice islands subsequently drifted to the east along the northern coast with a speed of more than I km/d. It finally blocked Robeson Channel between Canada and Greenland, thus preventing pack ice from entering it (Nutt, I966). Prior to these observations, after first sightings of similar ice islands in 1946 (Hattersley-Smith and others, 1955), intensive correlative studies between the structure of the Ward Hunt Ice Shelf and several ice islands floating in the Arctic Ocean were carried out (e.g. Koenig and others, 1952; Crary, 1958).

A fundamental part of the various field investigations on the Ward Hunt Ice Shelf has been the measurement of ice movements. A special precise horizontal survey of parts of the ice shelf was initiated in 1964 and conducted by Konecny and Faig (I966). This survey was also supposed to reveal evidence of any influence of ice deformation upon the regular east-west orientated "ridge-and-trough system" on the ice shelf. It is assumed (Hattersley-Smith, I957; Crary, 1958) that prevailing surface winds parallel to the ridge-and-trough system are the main cause of this phenomenon. 
FIELD WORK

A first survey, preceded by intensive reconnaissance, was carried out, due to logistic reasons, between June and July 1964. During this time of the year, the pack ice of the Arctic Ocean has usually drifted away, leaving large areas of open water. As a consequence, most of the time heavy fog prevents the necessary visibility. Therefore, in 1964, the field party was only able to set out four points $(15,16,17$ and 18$)$ on the ice shelf, connected with a well-fixed base line ( $\left.\mathrm{I} I-\mathrm{I}_{3}\right)$ on Ward Hunt Island by two quadrilaterals, two points of which (I2 and I4) are situated on the ice rise (Fig. I). All points on the ice were marked by aluminum tubes drilled vertically into the ice. For proper identification they were signalized by flagged bamboo poles. The end points of the base line were marked by bench marks cemented into

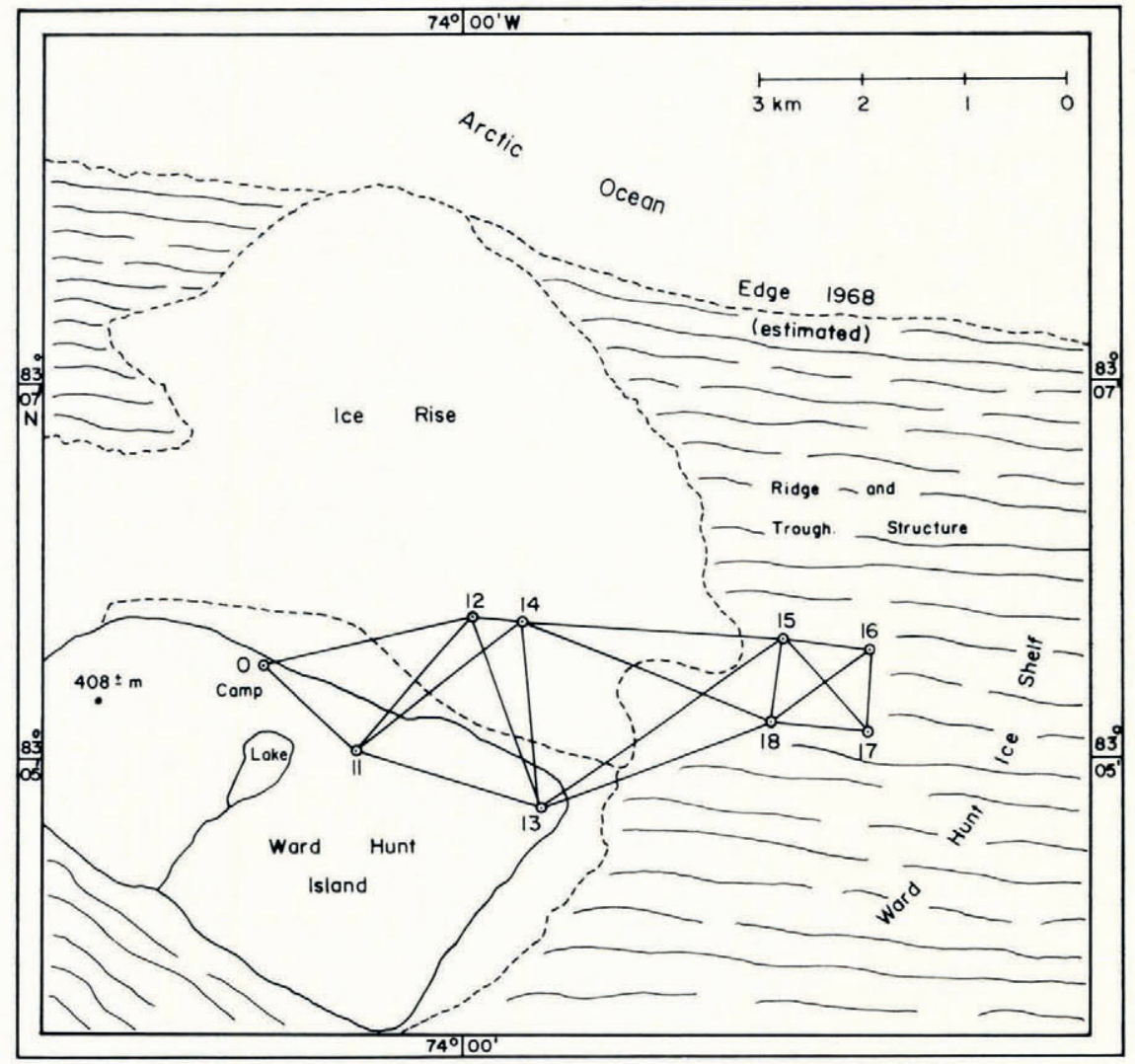

Fig. I. General situation on the Ward Hunt Ice Shelf and Ward Hunt Island.

solid rock. Due to unfavourable weather conditions, the network could not be surveyed as planned. Whereas the quadrilateral $\mathrm{I}_{5}-\mathrm{I} 6-\mathrm{I} 7-\mathrm{I} 8$ was completed, the connection to solid rock remained insufficient.

A second initial survey was organized in the following year but, due to the previous year's experience, about a month earlier. The expectation of avoiding the foggy season was only partly met since the weather proved to be unfavourable during much of the available time. The network was surveyed as completely as possible (i.e. almost all angles and distances), with a very high degree of redundancy. The results of both the 1964 and 1965 surveys have been discussed by Konecny and Faig (1966). 
It was not until 1968 that a re-survey of the Ward Hunt Ice Shelf network could be carried out. According to the experience gained during the two previous campaigns, a party consisting of S. E. Masry, R. Storm and the author (together with G. Hattersley-Smith and D. Finlayson) was flown to Ward Hunt Island as early as I2 May ig68. The same camp facilities as before could still be used.

A preliminary reconnaissance drive with a Snowmobile, which had been left behind by a third party coming from Disraeli Fiord, revealed that all points on the ice were still marked properly. In order to connect the camp with the survey net, a preliminary point (o) was chosen near the kitchen hut (Fig. I). Later, another point o on solid rock was finally selected beside the meteorological shelter (Fig. 3). The weather stayed extremely favourable during the entire month of May. Only occasional blizzards prevented measurements on a few days. Some light snowfall and fog occasionally caused low visibility towards the end of May.

The survey was started at the camp, progressing towards the east. Due to the early season, the solid ground on the island was still covered with snow. This and the fact that the northern part of the island does not receive direct sunlight during the daytime were probably the reasons that bench mark I I, situated on a steep rock outcrop, could not be found at the first attempt. The survey, however, was carried on until a second search revealed the mark later. Therefore, all previously measured directions and distances which included point I I had to be re-measured. Consequently, horizontal directions were measured with a Wild $\mathrm{T}_{2}$ theodolite in three full sets, but all vertical angles were measured in one set only. A Geodimeter model 6 with high-pressure mercury-vapor lamp was used for distance measurements; distances were measured only once, except for one of the two diagonals of each quadrilateral, which was measured twice.

The entire survey equipment was loaded on a single Nansen sled pulled either by the Snowmobile, or later by a heavy John Deere tractor which turned out to be more reliable than the Snowmobile. Power for the geodimeter was supplied by a special motor generator constructed for geodimeter use only; it was mounted on the sled.

For the measurement of directions and distances, overcast weather provided optimal observing conditions. This was expected for angular observations as under such environmental conditions virtually no noise contrast disturbs the sight to the target. But this was also found to be true for distance measurements with the geodimeter; almost perfect reflections could be obtained from reflectors consisting of $3 \times 3$ retrodirective prisms over distances up to $3 \mathrm{~km}$, despite the very high global light intensity. Under such conditions, there was no need to use a black screen behind the reflectors as is recommended for the Geodimeter model 4 . On the other hand, during sunshine, air scintillation due to turbulent vertical air movement caused the signal to noise ratio to deteriorate considerably even for relatively short distances of I km when no artificial background was used. Generally, it seems that, due to the coaxial Cassegrain optics of transmitter and receiver and to a narrower modulated light beam, the Geodimeter model 6 is not as sensitive to background noise light as model 4 .

\section{DATA REDUGTion}

During the field period, when weather did not permit any measurements, and after all observations had been completed, the original observations were reduced in a preliminary way. This involved the computation of the meaned sets of directions on all stations which could be used later for the net adjustment. Furthermore, with the aid of vertical angles, all measured slope distances were reduced to the horizontal. All possible net conditions, such as station and angle conditions, and side and distance conditions were checked in each quadrilateral before leaving the survey area.

All required reductions were repeated at home after the close of the field operations. Any discrepancy between preliminary and final reduction was traced until the mistake was found. 
Therefore, all finally reduced observations listed in Table I have a high reliability. This is also reflected in their standard errors; the overall value for any direction (mean of three sets of two values each) is 2.0 seconds of arc, and the corresponding value for a distance is $0.015 \mathrm{~m}$. This last value corresponds to a value for an average distance of about $1.7 \mathrm{~km}$. The variation of the standard error with distance has been considered negligible; also the fact that a few of the distances were measured twice.

TABle I. Horizontal directions AND distances for the ig68 Survey

Horizontal directions in degrees, minutes and seconds of arc

\begin{tabular}{|c|c|c|c|c|c|c|c|c|c|}
\hline $\begin{array}{l}\text { Station } \\
\text { number }\end{array}$ & (o) & I I & 12 & 13 & $\begin{array}{c}\text { Target number } \\
\text { I4 }\end{array}$ & 15 & 16 & 17 & 18 \\
\hline$(0)$ & 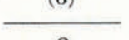 & o 1039.0 & 3053454.0 & - & - & - & - & - & - \\
\hline II & o & & 885455.0 & I 57 or 18.0 & 1002731.2 & - & 一 & - & 二 \\
\hline $\begin{array}{l}12 \\
13\end{array}$ & I $63 \underline{45}{ }^{52.5}$ & 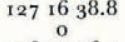 & $\begin{array}{llll}5 & 1 & 12 & 18.0\end{array}$ & 663520.0 & $\begin{array}{c}0 \\
654507.8\end{array}$ & $125 \overline{19} 08.0$ & $140 \overline{55} 48.0$ & 二 & Z \\
\hline 14 & - & 1 38 10 36.3 & 1792123.0 & 803327.0 & & o & - & - & 194637.0 \\
\hline $\begin{array}{l}15 \\
16\end{array}$ & 一 & - & - & I 334532.8 & I 734 I 55.0 & & 0 & $3^{8} 554^{8} .3$ & 88 о 108.0 \\
\hline $\begin{array}{l}16 \\
17\end{array}$ & - & - & 一 & - & - & 923521.8 & & o & $4^{8} 2959 \cdot 5$ \\
\hline 18 & $\begin{array}{l}\text { Average sta } \\
\sigma_{\mathrm{r}}=2.0 \mathrm{se}\end{array}$ & $\begin{array}{l}\text { dard error } \\
\text { onds of arc }\end{array}$ & - & $\overline{0}$ & $44 \overline{06}_{24.3}$ & $\begin{array}{r}443250.2 \\
1183858.5\end{array}$ & $\begin{array}{r}93 \text { or } 47.2 \\
1663229.0\end{array}$ & $205004^{1} \cdot 3$ & \\
\hline Iorizontal & istances betwee & stations in me & & & & & & & \\
\hline $\begin{array}{l}\text { Station } \\
\text { number }\end{array}$ & (o) & II & 12 & I3 & $\begin{array}{c}\text { Target number } \\
{ }_{14}\end{array}$ & I5 & I6 & 17 & 18 \\
\hline (o) & & 一 & 2139.428 & - & - & - & 一 & - & - \\
\hline II & & {[} & I 744.107 & I 951.226 & 2107.793 & - & 一 & 一 & - \\
\hline 12 & & & 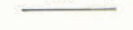 & 2076.330 & 530.066 & - & - & - & - \\
\hline $\begin{array}{l}13 \\
14\end{array}$ & & & & & I 928.139 & 2962.593 & - & - & $\begin{array}{l}2417.744 \\
2677.273\end{array}$ \\
\hline $\begin{array}{l}14 \\
15\end{array}$ & & & & & & 2587.779 & 968.685 & I 292.416 & 908.497 \\
\hline $\begin{array}{l}16 \\
17\end{array}$ & & & & & & & & 812.944 & $\begin{array}{r}1304.921 \\
978.720\end{array}$ \\
\hline 18 & $\begin{array}{c}\text { Average st } \\
\qquad \sigma_{8}=\end{array}$ & dard error & & & & & & & \\
\hline
\end{tabular}

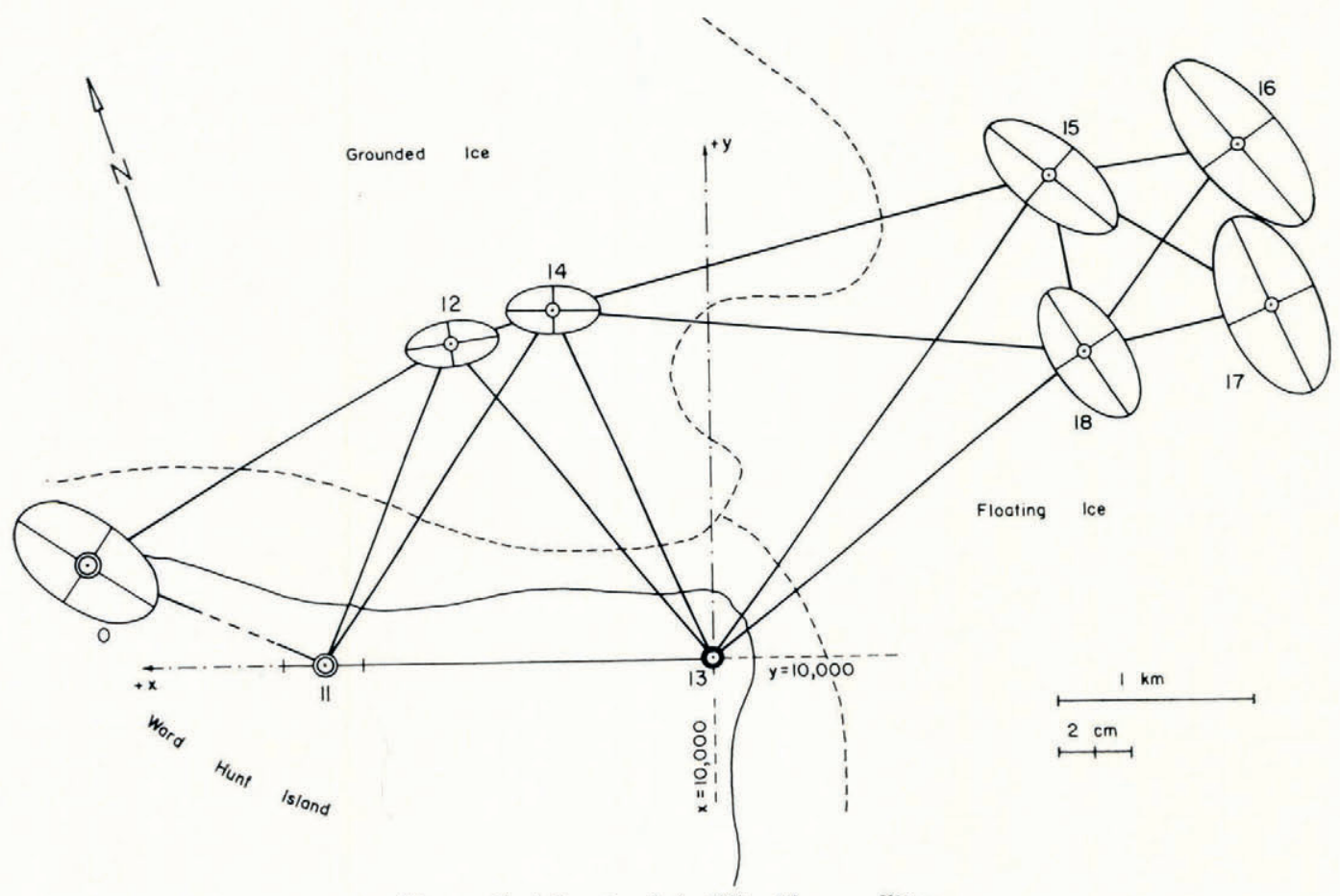

Fig. 2. Geodetic network (1968) with error ellipses. 
For the final adjustment of the network, a Cartesian coordinate system was chosen as indicated in Figure 2; point I 3 with the coordinates $x=y=1000 \mathrm{~m}$ and point I I with $y=10000 \mathrm{~m}$. A general FORTRAN IV program for the "adjustment or optimization of triangulation/trilateration/traversing or combinations of these by the parametric method", developed by J. S. Allman (Department of Surveying, University of New South Wales, Australia), provided the final adjustment of all observations, resulting in the most probable coordinates of the other points in the network. The positional accuracy (with respect to point I3) of these adjusted points is expressed by their computed error ellipses, shown in Figure 2. As expected from the special configuration of the network, the quadrilateral of most concern (viz. $\mathrm{I}_{5}-\mathrm{I} 6-\mathrm{I} 7-\mathrm{I} 8$ ) has maximal errors of $0.03 \mathrm{~m}$ in position. The actually

Table II. Adjusted coordinates, displacements and velocities

\begin{tabular}{|c|c|c|c|c|}
\hline \multirow[t]{2}{*}{$\begin{array}{l}\text { Point } \\
\text { number }\end{array}$} & \multicolumn{2}{|c|}{$\begin{array}{c}\text { Adjusted coordinates } x, y \text { after } \\
\text { scale adjustment for the two } \\
\text { surveys }(\mathrm{m})\end{array}$} & \multirow{2}{*}{$\begin{array}{l}\text { Coordinate } \\
\text { displacements } \\
\Delta x, \Delta y \\
\mathrm{~m}\end{array}$} & \multirow{2}{*}{$\begin{array}{c}\text { Velocity } \\
u, v \\
\text { m year }\end{array}$} \\
\hline & 1965 & 1968 & & \\
\hline o & 一 & $\begin{array}{l}\text { 13 } 128.980 \\
10517.648\end{array}$ & - & - \\
\hline II & $\begin{array}{l}\text { I I } 95^{1.2} \cdot 26 \\
\text { 10 } 000.000\end{array}$ & $\begin{array}{l}\text { I I } 95^{1.256} \\
\text { Io } 000.000\end{array}$ & - & - \\
\hline 12 & $\begin{array}{ll}\text { I I } 300.80 \text { I } \\
\text { I I } 6 \text { I } 8.348\end{array}$ & $\begin{array}{ll}\text { I I } & 300.884 \\
\text { I I } & 6 \text { I } 8.330\end{array}$ & $\begin{array}{l}+0.083 \\
-0.018\end{array}$ & $\begin{array}{l}+0.028 \\
-0.006\end{array}$ \\
\hline 13 & $\begin{array}{l}10000.000 \\
10000.000\end{array}$ & $\begin{array}{l}10000.000 \\
10000.000\end{array}$ & - & - \\
\hline I 4 & $\begin{array}{l}\text { Io } 789.834 \\
\text { I I } 758.947\end{array}$ & $\begin{array}{l}\text { Io } 789.8 \text { I I } \\
\text { I } 758.938\end{array}$ & $\begin{array}{l}-0.023 \\
-0.009\end{array}$ & $\begin{array}{l}-0.008 \\
-0.003\end{array}$ \\
\hline${ }^{15}$ & $\begin{array}{r}8287.122 \\
12415.633\end{array}$ & $\begin{array}{r}8287.176 \\
12417 \cdot 321\end{array}$ & $\begin{array}{r}+0.054 \\
+1.688\end{array}$ & $\begin{array}{l}+0.018 \\
+0.578\end{array}$ \\
\hline I6 & $\begin{array}{r}7328.759 \\
12557.812\end{array}$ & $\begin{array}{r}7328.971 \\
12559.471\end{array}$ & $\begin{array}{r}+0.212 \\
+1.659\end{array}$ & $\begin{array}{l}+0.073 \\
+0.568\end{array}$ \\
\hline I7 & 7 I 73.190 & 7173.473 & +0.283 & +0.097 \\
\hline I8 & $\begin{array}{rr}\text { I I } & 760.097 \\
8 & \text { I } 22.733 \\
\text { I I } 522.499\end{array}$ & $\begin{array}{r}\text { II } 76 \text { I. } 534 \\
8 \text { I } 22.873 \\
\text { I I } 523.814\end{array}$ & $\begin{array}{r}+\mathrm{I} .437 \\
+0.140 \\
+\mathrm{I} .315\end{array}$ & $\begin{array}{r}+0.493 \\
+0.048 \\
+0.451\end{array}$ \\
\hline
\end{tabular}

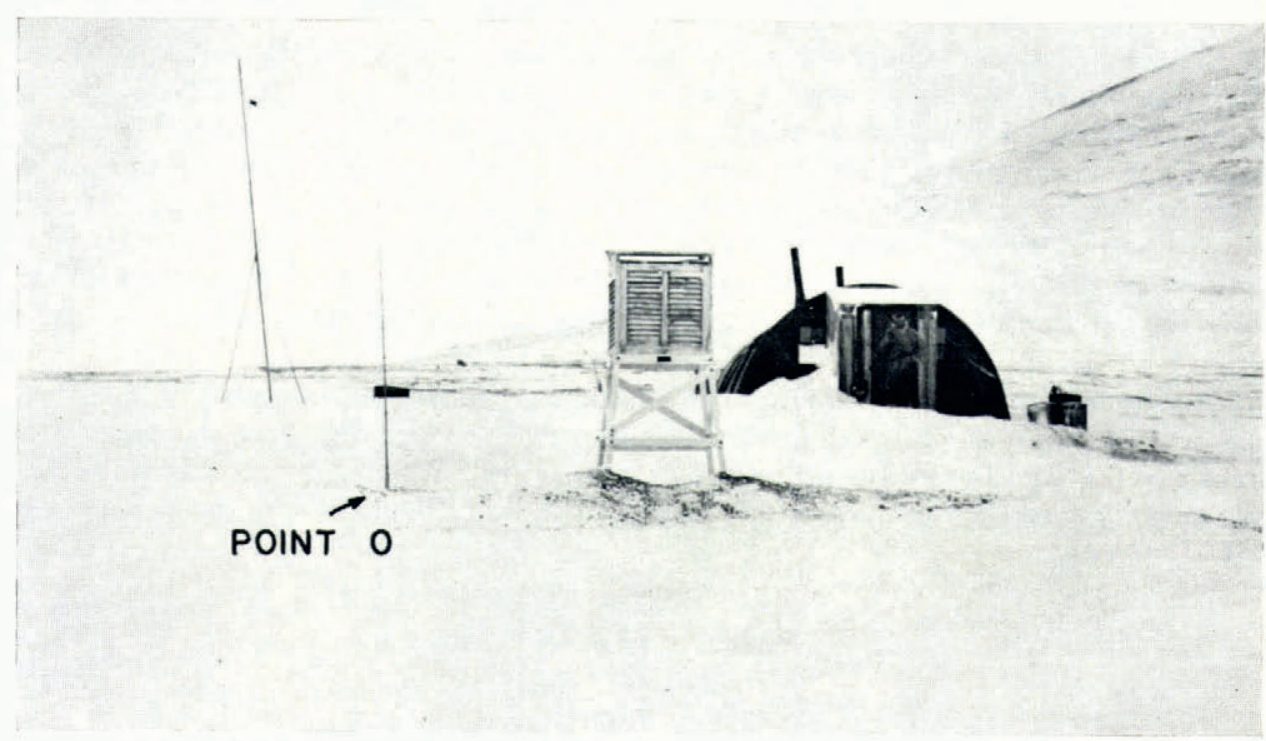

Fig. 3. "Monumented" point o at the Ward Hunt Island camp. 
computed coordinates are listed in Table II, together with the corresponding values of the I965 survey, taken from Faig (unpublished) and reduced to the same orientation of the coordinate system. The resulting variance factor of the adjustment was I.I I, which proves that the used a priori standard errors of the observations are good estimates.

Additional horizontal-angle measurements within the camp area provided the coordinate transfer from the preliminary chosen point (o) to a "monumented" point o (Fig. 3). Table II shows only the local coordinates of this point $o$.

\section{Data analysis}

\section{Ice movement}

The only fixed distance on solid ground in the network, common to both the 1965 and I968 surveys, lies between points I I and I3. A comparison of the adjusted values obtained from both surveys shows a difference of $0.028 \mathrm{~m}$ ( $1951.270 \mathrm{~m}$ in 1965 , I $951.242 \mathrm{~m}$ in $\mathrm{r} 968$ ), which is most likely due to random measurement errors as well as systematic scale differences between the two different geodimeters used. Before the coordinates of both surveys can be compared, this difference must be distributed over both surveys, i.e. the scale of each survey must be changed so that the average distance (I I-I3) becomes (I 95I.270+I 95 I.242)/2 $=\mathrm{I} 95 \mathrm{I} .256 \mathrm{~m}$. This means a slight scale change for both surveys. For the 1965 survey data, the scale must be reduced by about 7 p.p.m.; for the 1968 data, the scale must be increased by the same amount. The resulting coordinates, listed in Table II, are likely to provide a better comparison than the originally adjusted coordinates, although they only differ by at most $3 \mathrm{~cm}$ (point $\mathrm{I} 6$ ). In Table II, the coordinate differences $\Delta x, \Delta y$ (displacements) and the actual velocity in $\mathrm{m}$ year ${ }^{-1}$ are listed for all points on the ice. The time difference between both campaigns was 2 years and i I months.

The displacements of points 12 and 14 on the grounded ice rise (Fig. I), compared with those on the floating ice shelf, are very small. Any movements on this ice rise are only of local origin and are mainly dependent on the surface slope. Due to the various kinds of observational errors and possible changes in inclination of the survey markers, these determined displacements may not be of great significance.

There is an obvious movement of the ice shelf of about $0.5 \mathrm{~m}^{\text {year }}{ }^{-1}$ towards the north. Assuming this value as constant across the eastern part of the Ward Hunt Ice Shelf (east of Ward Hunt Island), the rate of discharge can be estimated. With the present distance of about ${ }_{1} 3 \mathrm{~km}$ between Ward Hunt Island and Cape Albert Edward, an ice thickness of $40 \mathrm{~m}$ (Crary, r 958) would give a discharge of $0.26 \times \mathrm{ro}^{6} \mathrm{~m}^{3}$ year $^{-1}$. Neglecting continuous smallscale ice calving, an area of approximately $6.5 \mathrm{~km}^{2}$ of ice will be formed each year. Despite this low value and the fact that the present ice front is fixed tightly at both ends, it seems rather difficult to predict another extensive break-up of the eastern ice shelf in the near future. Massive ice calving also depends to a great extent on oceanographic effects (e.g. tide and swell).

According to Nye (1959), an average deformation or strain-rate tensor within a quadrilateral can be determined, if all of its sides were measured twice at different instants of time. This is the result of the transformation properties of strain-rates. Assuming a steady-state ice flow, i.e. the velocity components $u, v$ are functions of $x, y$ only (independent of time), the Jacobian matrix

$$
F=\left[\begin{array}{ll}
\frac{\partial u}{\partial x} & \frac{\partial u}{\partial y} \\
\frac{\partial v}{\partial x} & \frac{\partial v}{\partial y}
\end{array}\right]
$$


expresses velocity changes due to small point displacements. The deformation itself is usually given by the components of the strain-rate tensor, defined by a symmetric matrix

$$
\begin{aligned}
E & =\frac{1}{2}\left(F+F^{T}\right), \\
E=\left[\begin{array}{l}
\dot{\epsilon}_{x x} \dot{\epsilon}_{x y} \\
\dot{\epsilon}_{y x} \dot{\epsilon}_{y y}
\end{array}\right] & =\left[\begin{array}{ll}
\frac{\partial u}{\partial x} & \frac{\mathrm{I}}{2}\left(\frac{\partial u}{\partial y}+\frac{\partial v}{\partial x}\right) \\
\frac{\mathrm{I}}{2}\left(\frac{\partial u}{\partial y}+\frac{\partial v}{\partial x}\right) & \frac{\partial v}{\partial y}
\end{array}\right] .
\end{aligned}
$$

The strain-rate tensor generally changes its components if the coordinate system changes its orientation. Defining an orthogonal rotation matrix by

$$
R=\left[\begin{array}{ll}
\cos \alpha & \sin \alpha \\
-\sin \alpha & \cos \alpha
\end{array}\right],
$$

where $\alpha$ is the angle between the original $x$-axis and the rotated $x^{\prime}$-axis, both the Jacobian $F$ as well as the strain-rate tensor $E$ are transformed into the coordinate system $x^{\prime}, y^{\prime}$ by the expressions

$$
\begin{aligned}
& F^{\prime}=R F R^{T}, \\
& E^{\prime}=R E R^{T} .
\end{aligned}
$$

One essential result is that the strain-rate $\dot{\epsilon}_{\alpha}$ in a certain direction (e.g. under an angle $\alpha$ against the original $x$-axis: $\dot{\epsilon}_{\alpha}=\dot{\epsilon}_{x x}^{\prime}$ ) can be expressed in terms of $\alpha$ and the three independent components of $E$ :

$$
\dot{\epsilon}_{\alpha}=\dot{\epsilon}_{x x} \cos ^{2} \alpha+\dot{\epsilon}_{x y} 2 \cos \alpha \sin \alpha+\dot{\epsilon}_{y y} \sin ^{2} \alpha .
$$

The six sides of the quadrilateral $\left(\mathrm{I}^{-16-17-18)}\right.$ therefore give rise to six equations in three unknowns $\dot{\epsilon}_{x x}, \dot{\epsilon}_{x y}, \dot{\epsilon}_{y y}$. These equations can be treated as observation equations from which best values of the strain-rate components are reduced according to the principle of least squares.* Table III gives the quantities and their values required for computation of the strain-rate tensor of quadrilateral $15-16-17-18$.

Table III. Strain-Rates $\dot{\epsilon}_{a}$ OF the Quadrilateral (I5-16-17-18)

$\begin{array}{cccc}\text { Side } & \Delta s & & \dot{\epsilon}_{a}=\frac{\Delta s}{s \Delta t} \\ & \mathrm{~m} & \mathrm{deg} & 10^{-5} \mathrm{year}^{-1} \\ 15-16 & -0.160 & 171.56 & -5.656 \\ 18-17 & -0.109 & 165.95 & -3.814 \\ 15-18 & +0.351 & -100.42 & +13.234 \\ 16-17 & +0.205 & -101.03 & +8.637 \\ 15-17 & -0.070 & -149.52 & -1.855 \\ 18-16 & +0.229 & 127.48 & +6.010\end{array}$

After solving the normal equations, the following components are obtained

$$
\begin{aligned}
& \dot{\epsilon}_{x x}=-5.6 \pm \mathrm{I} \cdot 3 \mathrm{IO}^{-5} \text { year }^{-1} ; \\
& \dot{\epsilon}_{x y}=+0.4 \pm \mathrm{I} \cdot 3 \mathrm{IO}^{-5} \text { year }^{-1} ; \\
& \dot{\epsilon}_{y y}=+\mathrm{I} \mathrm{I} .6 \pm \mathrm{I} \cdot 4 \mathrm{IO}^{-5} \text { year }^{-1} .
\end{aligned}
$$

The relatively large r.m.s. errors are caused partly by systematic velocity changes within the quadrilateral and partly by unavoidable measurement errors. Using $0.015 \mathrm{~m}$ as standard error for one distance measurement (Table I), the value increases for the difference of two

* Contrary to Nye (1959), the intersection of the two diagonals is not used as a station. 
measurements to $0.015 \times 2^{\frac{1}{2}}=0.023 \mathrm{~m}$. This yields an a priori standard error for the strainrate $(s=\mathrm{I} 000 \mathrm{~m}, t=2.9$ year $)$ of $0.8 \times \mathrm{IO}^{-5}$ year ${ }^{-1}$, which part can be considered as accidental.

The directions of the principal strain-rates are parallel to the principal axes of the tensor ellipse. Whereas these directions are given by the eigenvectors of the strain-rate tensor, the principal strain-rates are identical with its eigenvalues. The eigenvalue problem leads to a solution of the quadratic equation

$$
\lambda^{2}-\lambda\left(\dot{\epsilon}_{x x}+\dot{\epsilon}_{y y}\right)-\left(\dot{\epsilon}^{2} x y-\dot{\epsilon}_{x x} \cdot \dot{\epsilon}_{y y}\right)=0,
$$

resulting in the two eigenvalues

$$
\lambda_{\mathrm{I}}=\mathrm{I} . \mathrm{I} 7, \lambda_{2}=-0.5^{6} \times \mathrm{IO}^{-4} \text { year }^{-1} .
$$

The first value is orientated within the coordinate system according to its eigenvector $\left(\xi_{\mathrm{I}}=\mathrm{I} ; \eta_{\mathrm{I}}=\mathrm{I} \mathrm{I} . \mathrm{I}\right)$ as the result of either of the two equations

$$
\begin{gathered}
\left(\dot{\epsilon}_{x x}-\lambda_{\mathrm{I}}\right)+\dot{\epsilon}_{x y} \eta_{\mathrm{I}}=0, \\
\dot{\epsilon}_{x y}+\left(\dot{\epsilon}_{y y}-\lambda_{\mathrm{I}}\right) \eta_{\mathrm{I}}=0 .
\end{gathered}
$$

As shown in Figure 4, an obvious expansion occurs parallel to the main ice flow and compression perpendicular to it. Since the ridges and troughs (Fig. I) are orientated parallel to the main ice compression, they cannot be originated by internal ice forces. This would be in accordance with Hattersley-Smith's (1957) theory.

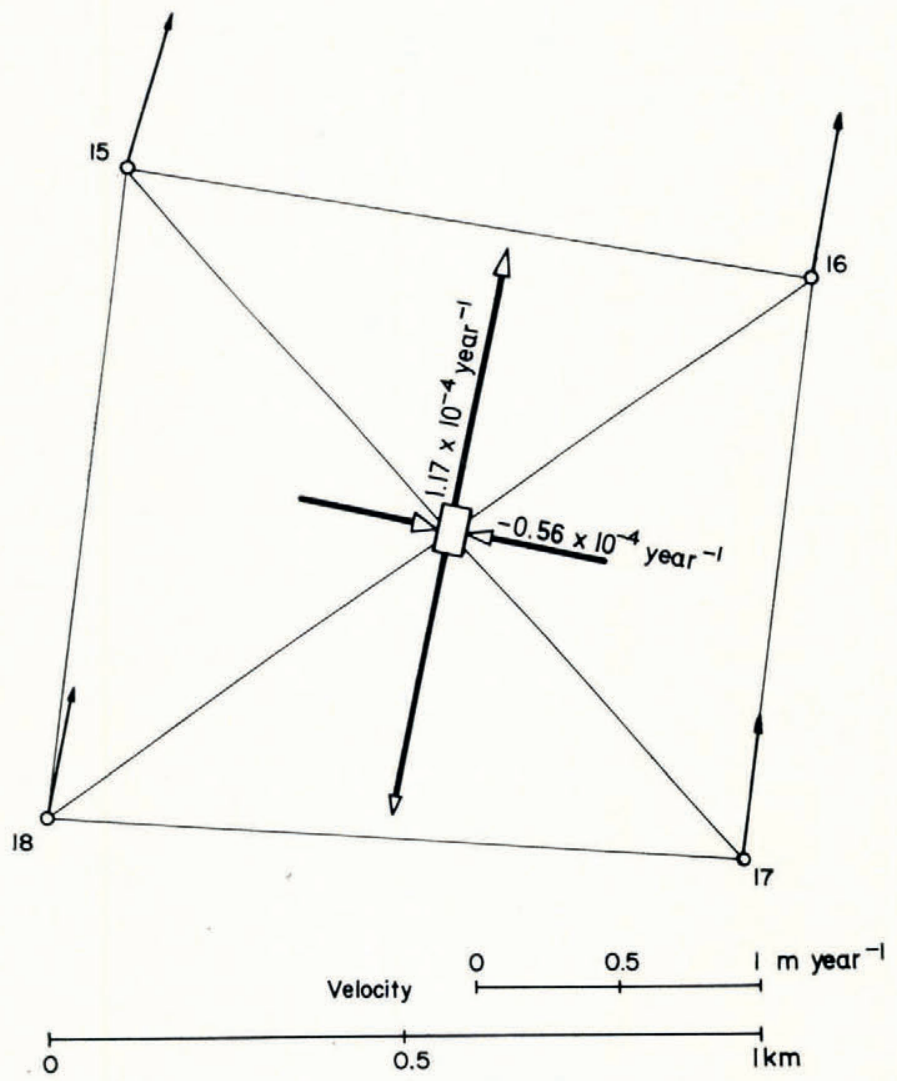

Fig. 4. Velocity vectors and principal axes of strain-rate tensor. 


\section{Ice stresses}

The determined strain-rates can be used to obtain some indication of the stress conditions on the ice shelf in general and within the measured strain figure in particular. Based on Glen's power flow law of the form $\dot{\epsilon}=(\tau \mid B)^{n}$, where $\dot{\epsilon}$ and $\tau$ are the second invariants of the strain-rate and stress-deviator tensors, respectively, ${ }^{*}$ defined by

$$
\begin{aligned}
\dot{\epsilon}^{2} & =\frac{1}{2} \dot{\epsilon}_{i j} \dot{\epsilon}_{i j} \\
\tau^{2} & =\frac{1}{2} \sigma_{i j}^{\prime} \sigma_{i j}^{\prime}, \quad i, j=\mathrm{I}, 2,3,
\end{aligned}
$$

some dynamic properties of the ice shelf can be estimated in a way similar to Budd's (1966) investigations on the Amery Ice Shelf, Antarctica. Application of theoretically derived equations by Weertman (I957) and Nye (1965) lead to good estimations for the flow parameters $B$ and $n$ of Glen's equation.

According to Nye (1965), the velocity $v$ in an infinitely deep channel of uniform width $2 a$ is given by

$$
v=v_{\max }\left\{\mathrm{I}-(y / a)^{n+\mathrm{r}}\right\},
$$

$y$ being the distance lateral to the flow, measured from the center to either of the two channel walls $\left(y_{\max }=a\right)$. For purely laminar flow, the velocity at the center is expressed as

$$
v_{\max }=\frac{2 a^{n+1}}{(n+\mathrm{I}) B^{n}}\left(\frac{\mathrm{d} p}{\mathrm{~d} x}\right)^{n},
$$

where $\mathrm{d} p / \mathrm{d} x$ is a uniform longitudinal pressure gradient. The flow through the channel between Ward Hunt Island and Cape Albert Edward, however, is somewhat complicated by the presence of the Marvin Islands (Fig. 5) and a number of smaller ice rises not taking part in the general flow. As indicated in Figure 5, two main ice streams may be distinguished, in which the orographically left one obviously has a higher velocity. An idealized velocity profile across the ice shelf, though difficult to determine, may be assumed to lie somewhere between the two profiles, corresponding to the entire width $2 a=$ I I. $6 \mathrm{~km}$, and to the partial width $2 a^{\prime}=5.4 \mathrm{~km}$ of the left stream only. The maximum velocities at the centers of two such channels can be determined from Equation (I), since $v=0.53 \mathrm{~m}^{\text {year }}{ }^{-1}$ is the known

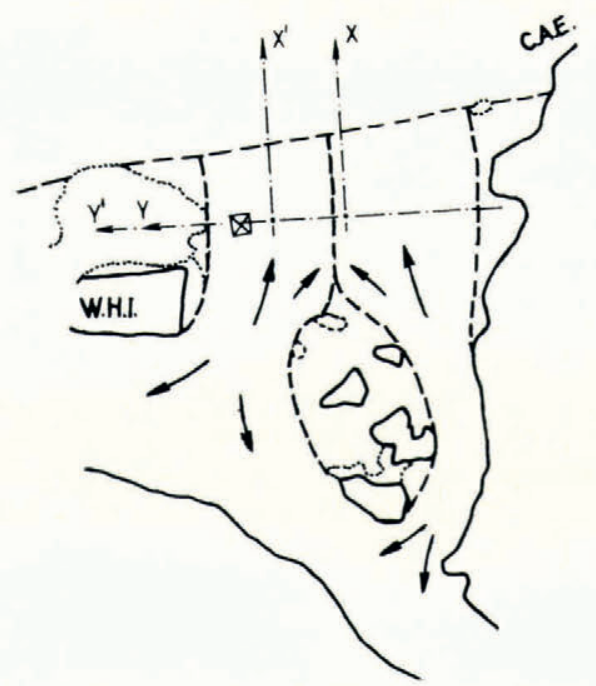

Fig. 5. Simplified flow of the Ward Hunt Ice Shelf between Ward Hunt Island (W.H.I.) and Cape Albert Edward (C.A.E.).

* Also called effective shear strain-rate and shear stress, respectively. 
velocity within the strain figure situated about $1.4 \mathrm{~km}$ apart from the Ward Hunt ice rise. For different values of $n$, these center velocities are listed in Table IV. Also listed are the lateral velocity gradients $\mathrm{d} v / \mathrm{d} y, \mathrm{~d} v / \mathrm{d} y^{\prime}$, respectively, obtained simply by differentiation of Equation (I). An average lateral velocity gradient estimated from the corner velocities of

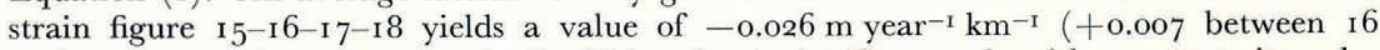
and $I_{5},-0.059$ between $I_{7}$ and $\mathrm{I}_{8}$ ). This value is significant only with respect to its order of magnitude, the corner velocities already having standard errors of $\pm 0.02 \mathrm{~m} \mathrm{year}^{-1}$. The most probable exponent (Table IV) seems to be very close to $n=4$.

TAble IV. Central velocities and their lateral gradients for entire and PARTIAL ICE-SHELF WIDTH

\begin{tabular}{|c|c|c|c|c|}
\hline$n$ & I & 2 & 3 & 4 \\
\hline $\begin{array}{l}v_{\max }\left(\mathrm{m}_{\text {year }}-1\right. \\
\mathrm{d} v / \mathrm{d} y\left(\mathrm{~m}_{\text {year }}^{-1} \mathrm{~km}^{-\mathrm{I}}\right)\end{array}$ & $\begin{array}{c}1.25 \\
-0.327\end{array}$ & $\begin{array}{c}0.94 \\
-0.282\end{array}$ & $\begin{array}{c}0.79 \\
-0.239\end{array}$ & $\begin{array}{c}0.71 \\
-0.204\end{array}$ \\
\hline$v^{\prime} \max \left(\mathrm{m}\right.$ year $\left.^{-1}\right)$ & o.695 & 0.597 & 0.560 & 0.545 \\
\hline $\mathrm{d} v / \mathrm{d} y^{\prime}\left(\mathrm{m} \operatorname{year}^{-1} \mathrm{~km}^{-\mathrm{I}}\right)$ & -0.249 & -0.153 & -0.070 & -0.054 \\
\hline
\end{tabular}

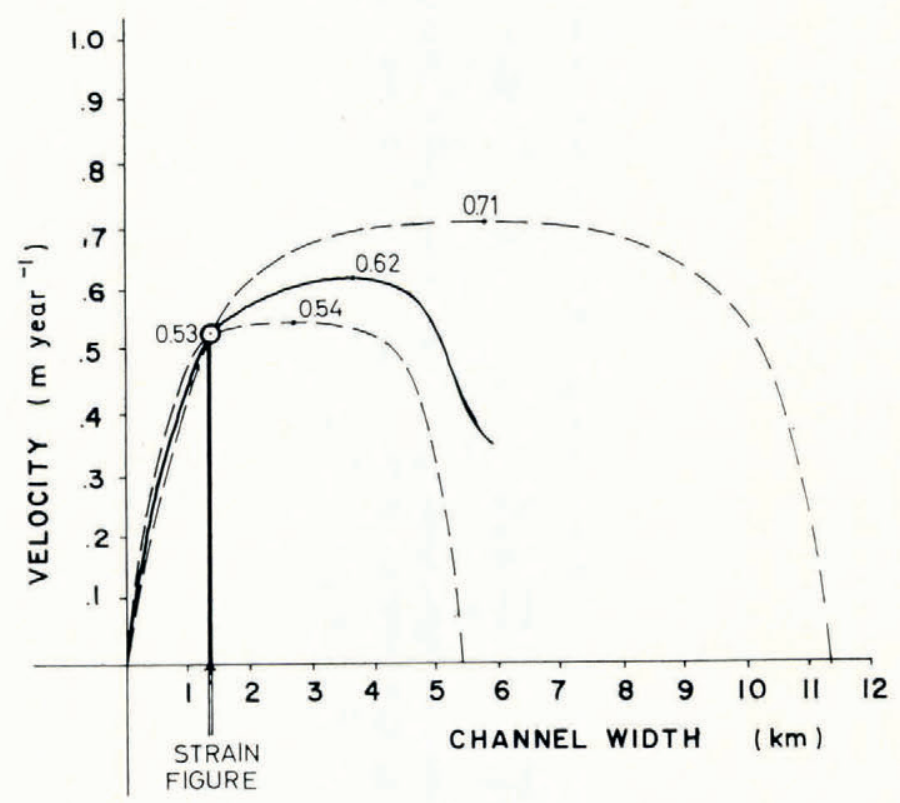

Fig. 6. Estimation of an idealized velocity profile.

In Figure 6 the two velocity profiles are plotted. An average curve with $v^{\prime \prime} \max =0.62 \mathrm{~m}$ year ${ }^{-1}$ and a fictitious width $2 a^{\prime \prime}=7.4 \mathrm{~km}$ are assumed in the following considerations.

For a determination of $B$, Budd (1966) gave the equation

$$
B\left\{\left[\frac{(n+\mathrm{I}) v}{2 a}\right]^{\mathrm{I} / n} \times \frac{\mathrm{I}}{a}-\frac{2}{n}\left(\frac{\mathrm{d} v}{\mathrm{~d} x}\right)^{(\mathrm{I} / n)^{-1}} \frac{\mathrm{d}^{2} v}{\mathrm{~d} x^{2}}\right\}=\frac{p g}{2} \times \frac{\mathrm{d} H}{\mathrm{~d} x},
$$

which relates the velocity $v$ and its longitudinal gradient $\mathrm{d} v / \mathrm{d} x$ to the boundary dimensions of the ice shelf (thickness $H$, width $2 a$ ), and the flow parameters $n$ and $B$. The gradient $\mathrm{d} v / \mathrm{d} x$ could be obtained similar to $\mathrm{d} v / \mathrm{d} y$ from the strain-figure data, but it is not needed since its gradient $\mathrm{d}^{2} v / \mathrm{d} x^{2}$, actually not known from the available observations, may be neglected because of the slow flow of the Ward Hunt Ice Shelf. The density of ice $\left(\rho=0.92 \mathrm{Mg} \mathrm{m}^{-3}\right)$ 
and an average thickness gradient $\left(\mathrm{d} H / \mathrm{d} s=3.0 \mathrm{~m} \mathrm{~km}^{-1}\right)$ were compiled from Crary's (1958) data. With the above values and $2 a=7.4 \mathrm{~km}$, we obtain $B=2.8 \times 10^{7} \mathrm{~N} \mathrm{~m}^{-2} \mathrm{~s}^{\frac{1}{3}}$ $\left(3.7\right.$ bar year $\left.^{\frac{1}{2}}\right)$.

The flow parameter $B$ is also a function of temperature $T$ of the form

$$
[B(T)]^{n}=\left[B\left(T_{0}\right)\right]^{n} \times \exp (Q / R T) \times \exp \left(-Q / R T_{0}\right) \quad(\text { Weertman, I957) }
$$

where $T_{0}$ is the temperature (in $\mathrm{K}$ ) of the melting point of ice, $B\left(T_{0}\right)=B_{0}$ is a constant equal to 2.67 bar year ${ }^{\frac{1}{4}}\left(2.0 \times \mathrm{IO}^{7} \mathrm{~N} \mathrm{~m}^{-2} \mathrm{~s}^{\frac{1}{2}}\right),{ }^{*} Q$ is an activation energy for creep and is equal to $68 \mathrm{~kJ} \mathrm{~mole}^{-1}$ (Mellor and Testa, I $969[\mathrm{a}],[\mathrm{b}]$ ), $R$ is the gas constant $8.32 \mathrm{~J} \mathrm{~K}^{-1} \mathrm{~mole}^{-1}$, and $n$ is the second flow parameter, taken here as 4 . To find $B$ for any temperature $T=T_{0}+t$ $\left(t\right.$ in $\left.{ }^{\circ} \mathrm{C}\right)$, the above equation can be transformed into

$$
[B(T)]^{n}=B_{0}{ }^{n} \times \exp \left[-\frac{Q}{R T_{0}^{2}} \times\left(t-t^{2} / T_{0}+t^{3} / \mathcal{T}_{0}^{2}-\ldots\right)\right] .
$$

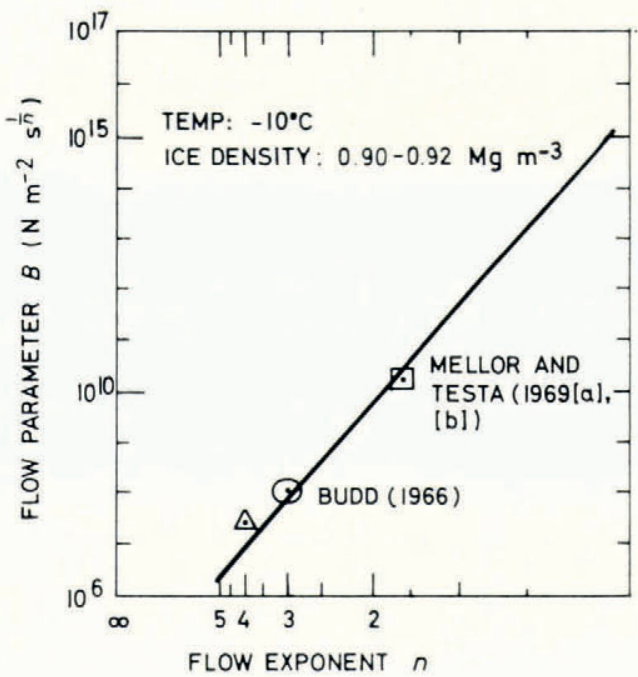

Fig. 7. Relationship between $B$ and $n$ as deduced from Weertman's equation and measured creep rate. Comparison with previous determination using Nye's equation $(\Delta)$ and experimental data $(\odot, \nabla)$.

The mean annual surface temperature of the ice shelf is $-18.5^{\circ} \mathrm{C}$ (Lyons and Ragle, I962), while the temperature at the base is $-1.8^{\circ} \mathrm{C}$, the freezing point of sea-water. Lyons and Ragle (1962) showed several graphs of temperature versus depth from different parts of the ice shelf, although none of these extended to the base. Temperature appears to increase linearly with depth, at least approximately. The mean annual ice temperature therefore is equal to $(-\mathrm{r} 8.5-\mathrm{r} .8) / 2=-\mathrm{I} 0.2^{\circ} \mathrm{C}$. This gives a value for $B$ of $2.7 \times 10^{7} \mathrm{~N} \mathrm{~m}^{-2} \mathrm{~s}^{\frac{1}{2}}$, which corresponds very well to the previous estimate of $2.8 \times 10^{8}$. In Figure 7 , the point corresponding to $\left(B=2.75 \times 10^{8} ; n=4\right)$ is plotted as a triangle.

By taking Nye's relation for steady-state creep for the case of zero transverse creep, and taking advantage of the fact that the ice shelf is floating, Weertman (1957) obtained for the creep rate

$$
K=\left(\frac{\rho_{\mathrm{i}} \Delta \rho g H}{4 \rho_{\mathrm{w}} \bar{B}}\right)^{n}
$$

\footnotetext{
* The value results from Weertman's (1957) constant 0.017 bar $^{-4.2}$ year $^{-1}$.
} 
where $\Delta \rho=\rho_{\mathrm{w}}-\rho_{\mathrm{i}}$ is the difference between the densities of water and ice, $H=$ ice thickness, and

$$
\bar{B}=\frac{\mathrm{I}}{H} \int_{0}^{H} B(T(z)) \mathrm{d} z .
$$

Weertman's equation for the extension rate provides the means of establishing a relation between the two flow parameters $n$ and $B$ for different values of $H$, the other quantities having known values. $K$ can be set equal to the measured longitudinal surface extension rate $1.17 \times 10^{-4}$ year $^{-1}\left(3.26 \times 10^{-12} \mathrm{~s}^{-1}\right)$, an assumption that is right insofar as $K$ is constant with depth, but is valid only near the center flow line of the ice shelf. However, Weertman's creep rate is still a good approximation to the extensional rate elsewhere. According to height measurements by $\mathrm{H}$. Serson, * the ice shelf around the deformation figure has a freeboard of $h=4.39 \mathrm{~m}$. The entire thickness of the ice shelf is given by

$$
H=h \frac{\rho_{\mathrm{w}}}{\rho_{\mathrm{w}}-\rho_{\mathrm{i}}},
$$

where $\rho_{\mathrm{w}}=1.03 \mathrm{Mg} \mathrm{m}^{-3}$ is the density of sea-water. The mean density $\rho_{\mathrm{i}}$ of the ice shelf lies somewhat between 0.90 and $0.92 \mathrm{Mg} \mathrm{m}^{-3}$ (Crary, I958), which results in an ice thickness $H$ between 35 and $4 \mathrm{I} \mathrm{m}$.

Taking $\rho_{\mathrm{i}}$ as parameter, $\bar{B}$ can be expressed in terms of $n$ :

$$
B=\frac{\rho_{\mathrm{i}} g h}{4^{\mathrm{I} / n}}
$$

In order to obtain a linear graph, $\bar{B}$ is represented in logarithmic and $n$ in hyperbolic scale in Figure 7 .

In terms of principal strain-rates, the effective shear strain-rate $\dot{\epsilon}$ is given by the expression

$$
2 \dot{\epsilon}^{2}=\dot{\epsilon}_{1}^{2}+\dot{\epsilon}_{2}^{2}+\dot{\epsilon}_{3}^{2},
$$

where $\dot{\epsilon}_{3}$ is determined through the continuity equation (no volume change)

$$
\dot{\epsilon}_{1}+\dot{\epsilon}_{2}+\dot{\epsilon}_{3}=0 \text {. }
$$

With $\dot{\epsilon}_{\mathrm{I}}=\mathrm{I} . \mathrm{I} 7 \times \mathrm{Io}^{-4}$ year $^{-1}, \dot{\epsilon}_{2}=-0.56 \times \mathrm{IO}^{-4}$ year $^{-1}$ (Fig. 3) one obtains $\dot{\epsilon}_{3}=-0.6 \mathrm{I} \times$ $\times$ IO $^{-4}$ year $^{-1}$. This yields an effective shear strain-rate of $\dot{\epsilon}=\mathrm{I}$.OI $\times$ IO $^{-4}$ year $^{-1}$. The effective shear stress is determined by $\tau=B \epsilon^{1 / n}$, and the principal deviatoric stresses by

$$
\sigma_{i}^{\prime}=(\tau / \dot{\epsilon}) \dot{\epsilon}_{i} \text {. }
$$

The result is $\tau=0.37 \mathrm{bar}, \sigma_{1}^{\prime}=0.43 \mathrm{bar}, \sigma_{2}^{\prime}=-0.20 \mathrm{bar}, \sigma_{3}^{\prime}=-0.22 \mathrm{bar}$. Since the vertical stress $\sigma_{3}=0$ on the ice surface, the actual horizontal principal stresses $\sigma_{\mathfrak{i}}$, given by the relationship

are

$$
\sigma_{i}^{\prime}=\sigma_{\mathrm{i}}-\frac{\mathrm{I}}{3} \sum_{k=1}^{3} \sigma_{k},
$$

$$
\begin{aligned}
& \sigma_{1}=2 \sigma^{\prime}{ }_{1}+\sigma^{\prime}{ }_{2}=0.65 \mathrm{bar}, \\
& \sigma_{2}=\sigma_{1}^{\prime}+2 \sigma_{2}{ }_{2}=0.02 \mathrm{bar} .
\end{aligned}
$$

\section{Elevations and atmospheric refraction}

Though primarily measured to reduce slope distances to horizontal distances, the vertical angles may be used for determining the elevations of all stations. They can also reveal some information about the refractive index of air during the period of observation. It is known

* Personal communication from Dr G. Hattersley-Smith. 
that in the lower atmospheric layers above sea ice, shelf ice or inland ice (see e.g. Liljequist, 1964) the gradient of the refractive index, as a direct function of the temperature gradient, can be extremely high. The reason lies in the radiation losses from the surface which may develop temperature inversions. Any ray of light extending between the surface and such an inversion is subject to a more or less large path curvature, which, under certain circumstances, may give rise to mirages. The effect forbids any precise trigonometric height measurements. Only if vertical angles and temperature gradients are measured simultaneously at both stations, more reliable heights may be obtained. If the distance between two such stations is not too long, the path of the light ray can be assumed as part of a vertical circle. Brocks (I954), amongst others, showed that, along a horizontal surface, the curvature of a light path is directly proportional to the air-temperature gradient:

$$
K=\frac{\mathrm{I}}{R^{\prime}}=c \times \frac{P}{\mathrm{I} \text { OOO }} \frac{\partial T}{\partial z},
$$

if influences of air and vapor pressure are neglected. In surveying, a so-called "local coefficient of refraction" (or relative curvature of light) is used, defined as

$$
k=\frac{R}{R^{\prime}}=K R
$$

with $R=$ radius of the Earth. In practice, this quantity is taken as a constant (e.g. $k=$ o.I3), if the light path is sufficiently far away from the surface. In polar regions, however, $k$ may assume values higher than 3 , and even negative values are common.

At all stations on the Ward Hunt Ice Shelf, vertical angles were measured. Therefore, both angles are given between two neighbouring stations, although these were not measured at the same instant of time. By means of given instrument and target heights above corresponding stations and the distance between instrument and target, the actual light path can be approximated by a circular arc, the radius of which is equal to the inverse of an average path curvature $K$. Thus all elevation differences along the lines of the network (Fig. I) can be determined. Since more observations are available than required, a height adjustment of the entire network can be carried out.

The result is shown in Table $\mathrm{V}$, where the elevation of station $\mathrm{I} 8$ is taken from a geometric level survey run by H. Serson in I 969 . All elevations can be considered to have a standard

\begin{tabular}{|c|c|}
\hline \multicolumn{2}{|c|}{$\begin{array}{l}\text { TABle V. Elevations OF WaRd Hun } \\
\text { ICE SHELF SURVEY STATIONS. REFERENC } \\
\text { POINT FOR ICE STATIONS IS TOP OF MARKE } \\
\text { FOR GROUND STATIONS BENCH MARK }\end{array}$} \\
\hline Station & $\begin{array}{c}\text { Elevation above sea-level } \\
\mathrm{m}\end{array}$ \\
\hline I I & 79.5 \\
\hline I 2 & 34.2 \\
\hline 13 & 20.2 \\
\hline 14 & 32.0 \\
\hline I 5 & 5.2 \\
\hline 16 & 6.8 \\
\hline 17 & 7.1 \\
\hline 18 & 5.8 \\
\hline
\end{tabular}
error of $0.2 \mathrm{~m}$ over the comparatively short distances involved.

Table VI shows refraction conditions of the lower atmosphere for various lines of sight (Fig. I), together with the resulting angles of refraction (i.e. vertical angle on a station between circular light path and straight line to opposite station), local refraction coefficients and computed temperature gradients. Of particular interest are observation periods $\mathrm{I}$ and 2 (column I), because of equal elevation of all stations under consideration. Whereas typical 
white-out conditions yield a refraction coefficient of 0.6 , the "mixed" values during the second period show a rather high influence of the pure radiation condition (clear sky), resulting in a somewhat extrapolated coefficient of $1.5+(1.5-0.6)=2.4$; note the extremely high temperature gradient of $0.3 \mathrm{deg} \mathrm{m}^{-1}$. For observation periods 3 and 4 , a proper analysis is virtually impossible with the sparse data available, due to asymmetric vertical profiles with height differences up to $50 \mathrm{~m}$. The negative coefficient of refraction along line $I_{I}-I_{3}$ is a result of the dark, snow-free and heated terrain surface with associated heat convection into the surface layers of air.

\begin{tabular}{|c|c|c|c|c|c|}
\hline & Line & $\begin{array}{l}\text { Refraction } \\
\text { angle } \\
\text { rad }\end{array}$ & \multicolumn{2}{|c|}{$\begin{array}{l}\text { Local refraction } \\
\text { coefficient } \\
k\end{array}$} & General conditions \\
\hline $\mathbf{I}$ & $\begin{array}{l}15-16 \\
15-17 \\
16-17\end{array}$ & $\begin{array}{l}0.000057 \\
0.000051 \\
0.000046\end{array}$ & $\begin{array}{l}0.49 \\
0.5^{1} \\
0.7^{1}\end{array}$ & 0.6 & $\begin{array}{l}\text { White-out during both directions } \\
\text { Air pressure } p=1023 \mathrm{mbar} \\
\text { Air temperature } t=-8^{\circ} \mathrm{C} \\
\text { Horizontal profile } \\
\text { Temperature gradient } 8^{\circ} \mathrm{C} / 100 \mathrm{~m}\end{array}$ \\
\hline 2 & $\begin{array}{l}15-18 \\
16-18\end{array}$ & $\begin{array}{ll}0.000 & 135 \\
0.000 & 089\end{array}$ & $\begin{array}{l}\text { I. } 76 \\
1.29\end{array}$ & $\begin{array}{c}(1.5) \\
2.4\end{array}$ & $\begin{array}{l}\text { White-out forward; r } 023 \mathrm{mbar} ;-8^{\circ} \mathrm{C} \\
\text { Clear sky backward; } 1 \text { o26 mbar; }-9^{\circ} \mathrm{C} \\
\text { Horizontal profile } \\
\text { Temperature gradient } 30^{\circ} \mathrm{C} / 100 \mathrm{~m}\end{array}$ \\
\hline 3 & $\begin{array}{l}13-18 \\
14-18\end{array}$ & $\begin{array}{l}0.00024^{1} \\
0.000270\end{array}$ & $\begin{array}{l}\text { I. } .28 \\
\text { I. } 29\end{array}$ & $I \cdot 3$ & $\begin{array}{l}\text { Clear sky in both directions } \\
t=-7^{\circ} \mathrm{C}, p=\mathrm{I} \text { o20 mbar } \\
\text { Typical effect of surface depression }\end{array}$ \\
\hline 4 & $\begin{array}{l}\mathrm{II}-12 \\
\mathrm{II}-14\end{array}$ & $\begin{array}{l}\text { o.ooo } 064 \\
\text { o.0oo } 083\end{array}$ & $\begin{array}{l}0.40 \\
0.60\end{array}$ & 0.5 & $\begin{array}{l}\text { Clear sky in both directions } \\
t=-9^{\circ} \mathrm{C}, p=\text { I o20 mbar } \\
\text { Point I I on a high rock }\end{array}$ \\
\hline 5 & II -13 & -0.000039 & -0.26 & & $\begin{array}{l}\text { Clear sky in both directions } \\
t=-9^{\circ} \mathrm{C} \ldots-5^{\circ} \mathrm{C}, p=\mathrm{I} \text { o2 } 3 \text { mbar } \\
\text { Light path above snow-free terrain }\end{array}$ \\
\hline
\end{tabular}

\section{AcKnowledgements}

This work was sponsored by the Defence Research Board under Grant No. DRB-350I-02 given to Dr G. Konecny, University of New Brunswick, and to a minor part by the National Research Council (Grant No. A-4377). The logistic support of the Defence Research Board arranged by Dr G. Hattersley-Smith is gratefully acknowledged. The author is indebted to him for providing fruitful discussions. Invaluable assistance of Dr S. El Masry and Richard Storm in the field, and of Mr Chi-Kin Wong in the office is appreciated. Dr A. Chrzanowski, Dr G. Konecny, Dr S. Paterson and Dr J. Weertman read the manuscript, improved the English and made valuable and useful suggestions, most of which could be considered.

\section{MS. received 27 Fanuary 1970}

\section{REFERENGES}

Brocks, K. 1954. Eine räumlich integrierende optische Methode für die Messung vertikaler Temperatur- und Wasserdampfgradienten in der untersten Atmosphäre. Archiv für Meteorologie, Geophysik und Bioklimatologie, Ser. A, Bd. 6, Ht. 3-4, p. 370-402.

Budd, W. r966. The dynamics of the Amery Ice Shelf. Fournal of Glaciology, Vol. 6, No. 45, p. 335-58.

Crary, A. P. 1958. Arctic ice island and ice shelf studies. Part I. Arctic, Vol. I I, No. I, p. 2-42.

Faig, W. Unpublished. A report on the triangulation-trilateration surveys in 1964 and 1965 at the Ward Hunt Ice Shelf. [Report of the Surveying Engineering Division, University of New Brunswick, 1965.]

Hattersley-Smith, G. 1957. The rolls on the Ellesmere ice shelf. Arctic, Vol. ro, No. 1, p. 32-44.

Hattersley-Smith, G. I963. The Ward Hunt Ice Shelf: recent changes of the ice front. Journal of Glaciology, Vol. 4 , No. 34 , p. 41 $5^{-24}$. 
Koenig, L. S., and others. 1952. Arctic ice islands, [by] L. S. Koenig, K. R. Greenaway, Moira Dunbar and G. Hattersley-Smith. Arctic, Vol. 5, No. 2, p. 66-103.

Konecny, G., and Faig, W. 1966. Studies of ice movement on the Ward Hunt Ice Shelf by means of triangulationtrilateration. Arctic, Vol. 19, No. 4, p. 337-42.

Liljequist, G. H. 1964. Special studies. B. Refraction phenomena in the polar atmosphere (Maudheim, $\left.71^{\circ}{ }^{\prime} \mathrm{S}, 10^{\circ} 56^{\prime} \mathrm{W}\right)$. Norwegian-British-Swedish Antarctic Expedition, 1949-52. Scientific Results, Vol. 2, Part $2 \mathrm{~B}$, p. 89-120.

Lyons, J. B., and Ragle, R. H. 1962. Thermal history and growth of the Ward Hunt Ice Shelf. Union Géodésique et Géophysique Internationale. Association Internationale d'Hydrologie Scientifique. Commission des Neiges et Glaces. Colloque d'Obergurgl, $10-9-18-9$ I962, p. 88-97.

Mellor, M., and Testa, R. 1969[a]. Creep of ice under low stress. Journal of Glaciology, Vol. 8, No. 52, p. 147-52. Mellor, M., and Testa, R. ${ }^{969[\mathrm{~b}]}$. Effect of temperature on the creep of ice. Journal of Glaciology, Vol. 8, No. 52, p. $131-45$.

Nutt, D. C. 1966. The drift of ice island WH-5. Arctic, Vol. 19, No. 3, p. $244-62$.

Nye, J. F. 1959. A method of determining the strain-rate tensor at the surface of a glacier. Fournal of Glaciology, Vol. 3, No. 25, p. 409-19.

Nye, J. F. 1965 . The flow of a glacier in a channel of rectangular, elliptic or parabolic cross-section. Fournal of Glaciology, Vol. 5, No. 41, p. 66r-go.

Weertman, J. 1957. Deformation of floating ice shelves. Fournal of Glaciology, Vol. 3, No. 21, p. 38-42. 